\title{
Historical damage pattern and causes of differential damage: an approach based on combining geophysical prospecting, geological and historical-technical data
}

\author{
F. T. Gizzi ${ }^{1}$, V. Lapenna ${ }^{2}$, N. Masini ${ }^{1}$, and E. Rizzo $^{2}$ \\ ${ }^{1}$ Istituto per i Beni Archeologici e Monumentali (IBAM) CNR-Area della Ricerca-Tito Scalo (PZ)-C.da S. Loja 85050, Italy \\ ${ }^{2}$ Istituto per le Metodologie Avanzate di Analisi Ambientali (IMAA)- CNR-Area della Ricerca-Tito Scalo (PZ)-C.da S. Loja \\ 85050 , Italy
}

Received: 5 July 2008 - Revised: 11 October 2008 - Accepted: 14 October 2008 - Published: 14 November 2008

\begin{abstract}
We describe a multidisciplinary and interdisciplinary method to analyse the causes of differential macroseismic effects caused by an earthquake in a historical town. We illustrate the method with a case study based on analysing the damage caused by the 1930 Irpinia earthquake $(\mathrm{Me}=6.7)$ in Melfi, a town in southern Italy. A damage pattern map was already available for this site.

To understand the anomalies of Melfi damage, we used an integrated approach that combines geological surveys, geophysical prospecting and analysis of unpublished technicalhistorical data.

Geo-electrical prospecting was adopted to infer the geological set-up and to estimate the thickness of shallow deposits. The results of the geophysical surveys were compared with detailed geological information derived from both in situ surveys and boreholes. Finally, cross-correlation among these data and technical reports coeval to the earthquake allowed us to create a complete picture of the possible causes of uneven damage.
\end{abstract}

\section{Introduction}

Detailed knowledge of the effects of past earthquakes can lead to a meaningful improvement in the "seismic features" of a town (e.g., Guidoboni et al., 2003; Gizzi, 2006).

It is possible to infer from a damage map the areas where highest damage occurred and where in-depth multidisciplinary and interdisciplinary analyses and surveys should be done. In this way, the causes of the differential damage, such as seismic amplification, landslides, geo-technical failure of the soils and/or building vulnerability, can be inferred.

This paper introduces a methodology for determining the causes of an uneven damage pattern in a town hit by a past earthquake.

To illustrate the methodology, we provide a case study of the 1930 Irpinia earthquake $(\mathrm{Me}=6.7)$ in Melfi, a medieval town located in southern Italy, for which a detailed damage pattern map was already available (Gizzi and Masini, 2004). The multidisciplinary and interdisciplinary approach is based on combining geological data, geophysical prospecting and technical-historical information.

The multidisciplinary approach has already proved be useful for analysing some aspects of natural events both related to seismic effects in urban areas and other natural phenomena.

As regards historical damage, works similar to what we are proposing here are few.

Among these, we cite the Palermo case study. To identify the causes of the uneven damage in Palermo some studies, examined as a whole, show an integrated use of geological, geotechnical, geophysical, and historical data (Guidoboni et al., 2003; Giammarinaro et al., 2005; Cara et al., 2008).

"Multi-level" approach involving historical, geological, and geophysical information is also adopted for analysing some aspects of other natural events, such as landslides. We refer, for example, to the approach to analyse both the causes of the landslide trigger and geomorphological risk of historical centres (Agnesi et al., 2005; Naudet et al., 2006). 


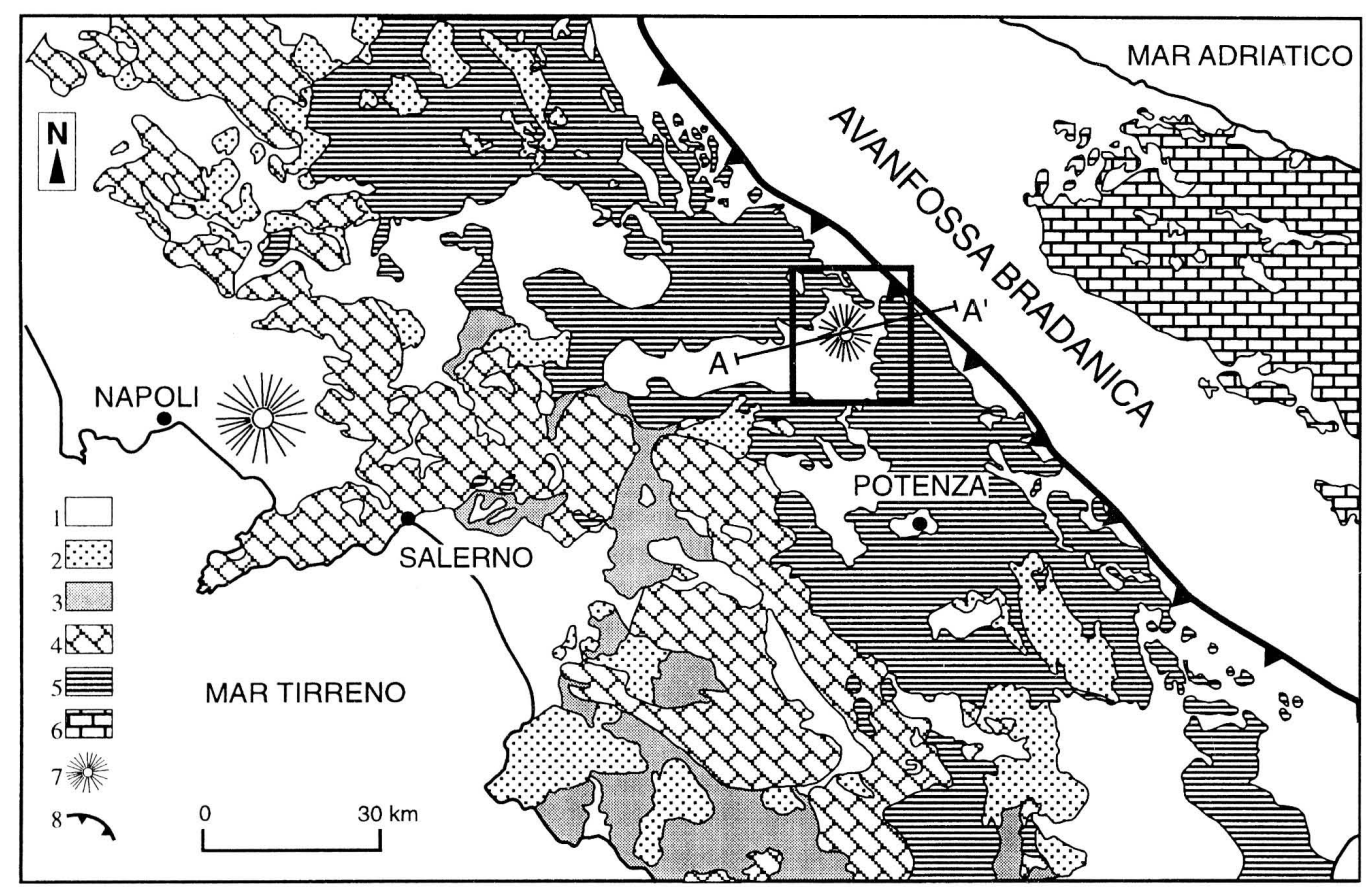

Fig. 1. Tectonic outline of the Southern Apennines. 1=Bradanic foredeep and intrapenninic sediments. Volcanoclastic rocks (plioquaternary); 2=Sinorogenic sediments (Miocene); 3=Liguride complex (Cretaceous-Oligocene); 4=Apennine platform carbonate (MesozoicCenozoic); 5=Lagonegro basin sediments (Trias-Miocene); 6=Apulian platform sediments (Trias-Pliocene); 7=Volcanoes; 8=Buried allochthonous front. Vulture area is shown from the rectangle (from Pescatore et al., 1999, modified).

\section{Regional and site geological settings}

Melfi, a town with about 17000 inhabitants, lies on a hilltop at the foot of the extinct Vulture volcano in the southern Apennines.

The Apenninic chain is a Neogene fold and thrust belt made up of complex imbricated tectonic units with duplex structures, dissected by normal faults (e.g., Patacca and Scandone, 1989). The chain is made up of Mesozoic-Paleogene sediments deposited in platform and basin paleogeographic domains that were involved in contractional episodes from late Oligocene-early Miocene times (e.g., Pescatore et al., 1999) (Fig. 1). Progressive eastward migration of compressional fronts was driven by gravity-sinking of the foreland lithosphere and related subduction roll-back (Malinverno and Ryan, 1986). Since the Pliocene, shortening has been replaced by extensional tectonics (e.g., Patacca et al., 1990). Present day stress field analysis suggests that the southern Apennines are affected by extension that occurs across normal faults mostly strike parallel to the chain (Frepoli and Amato, 1997; Montone et al., 1997).

During the Middle Pleistocene, the most recent chain deformation occurred in the southern and easternmost part of the Apennines (e.g., Scandone et al., 1992), and the history of the strato-volcano Vulture began.
The volcanic products are composed of highly undersaturated alkaline-potassic to ultra-potassic rocks such as foidites, tephrites, phonolites and trachites (e.g., Giannandrea et al., 2004) from $740 \pm 7$ to $141 \pm 11$ ky old (Buettner, 2006). Recently, the volcanic products have been grouped into two supersynthemes (Vulture Mount and Monticchio) and five synthemes (Schiattarella et al., 2005; Giannandrea et al., 2006). Melfi is located just in this geological background as shown by Fig. 2. From the figure, it emerges that the historical centre mainly lies on a hill top where there are outcrops of dark-grey lava rock locally known as Melfi Haüynophyre (Melfi Synthem). As described later, over the massive Haüynofiro lies a covering of highly variable thickness, made up of eluvial-colluvial and pyroclastic deposits. Beneath the foiditic lava lie both lacustrine and pyroclastic deposits (Rionero Subsynthem), which outcrop in the southern part of the hill foot. The most affected quarter (Bagni) is on pyroclastic deposits.

\section{Melfi and the 23 July 1930 earthquake}

The analysis of Melfi's seismic history shows that the town was hit by several strong earthquakes including the Irpinia earthquake on 23 July 1930 (Boschi et al., 2000). The seismic event, which had an epicentral intensity of Io $=X$ MCS and $\mathrm{Me}=6.7$, hit an area of about $6500 \mathrm{~km}^{2}$. 

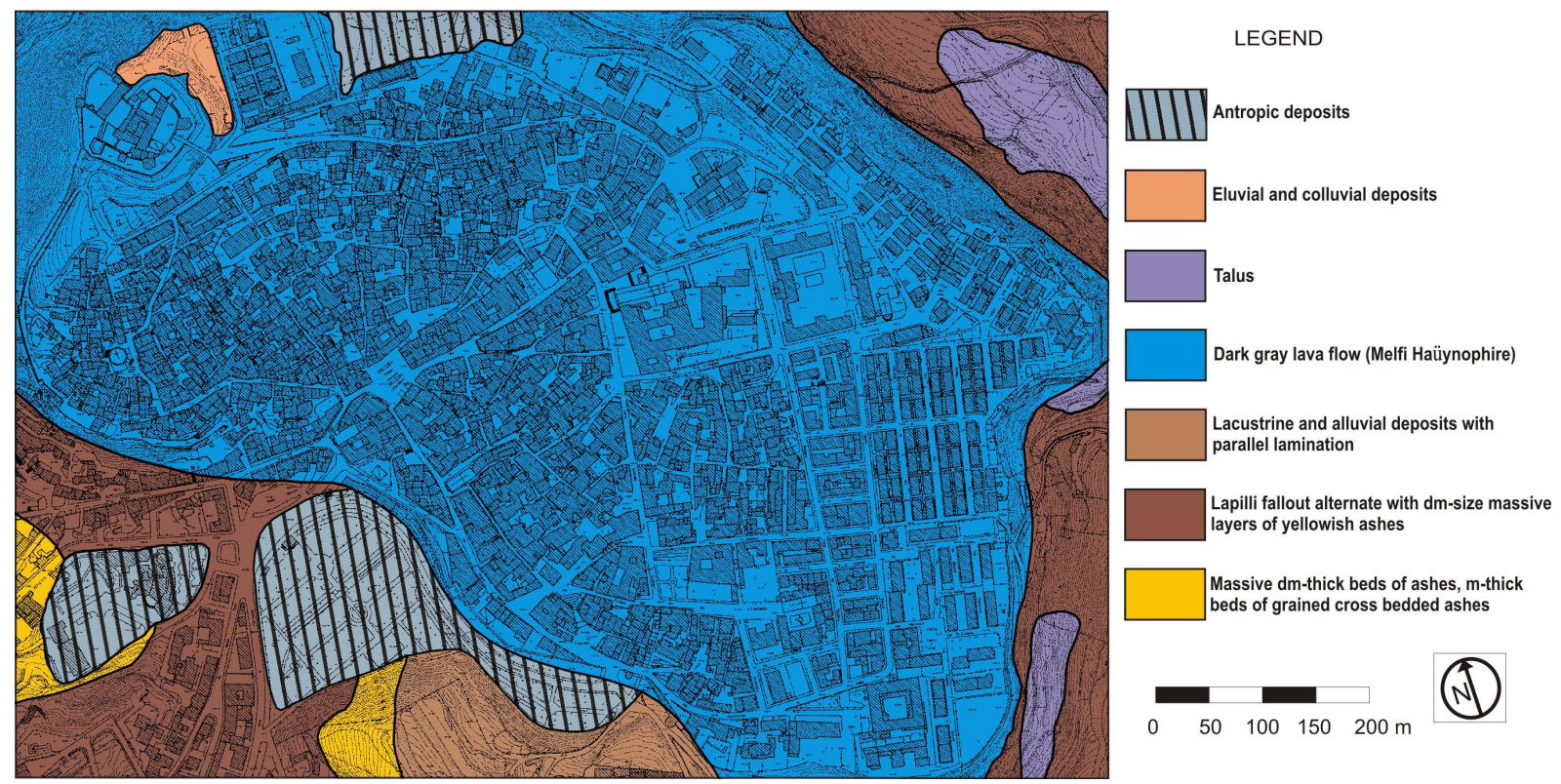

Fig. 2. Geological map of Melfi downtown.

Gizzi and Masini (2004) analysed the damage from this event in downtown Melfi, in detail. The data used to analyse the macroseismic effects were taken from about 2400 coevalto-earthquake unpublished technical reports that were drawn up house-by-house by civil engineers. In order to obtain a high spatial resolution of the seismic effects, all damage events were pinpointed on a coeval-to-earthquake map.

Figure 3 shows that the shaking was mainly felt in three areas: the south-western (coinciding with Bagno, Calcinaia, San Martino and Cappuccini quarters), central-eastern and southeastern sectors.

The damage analysis leads to a question: what were the causes of uneven urban effects? To determine this, we performed a cross-correlated analysis of geophysical surveys, geological data and historical-technical information.

Geo-electrical tomography was adopted to analyse the geological set-up and to estimate the thickness of shallow deposits. The results of the geophysical surveys were compared with both detailed geological information from in situ surveys and with boreholes. Last, analysing unpublished archival technical reports allowed us to draw a complete picture of the possible causes of differential damage.

\section{Geophysical prospecting technique}

Over the last several years, geophysical techniques have become a valuable diagnostic tool for subsoil investigations, as they are cost effective, non-intrusive and quick.

Of the several geophysical methods used, Electrical Resistivity Tomography (ERT) is the most popular owing to its ability to detect variations of electrical features in the subsoil.
ERT consists in measuring the resistivity values (Ohm.m) of the subsoil computed from the electrical field associated with injecting current at the ground surface. ERT provides information about geological structure geometries such as fault planes in tectonically active areas (Caputo et al., 2003; Colella et al., 2004), landslide bodies (Lapenna et al., 2003) and buried archaeological features (Rizzo et al., 2005).

In this work, several ERT studies were carried out in downtown Melfi to define geological features.

\subsection{ERT surveys and subsoils}

Seven ERT surveys were carried out using a Syscal R2 georesistivimeter equipped with a multi-electrode switch system with 32 channels. Each channel was connected with a steel electrode. To have good contact between the electrode and the soil, a small hole filled with clay and saltwater was dug along the profile for each channel position.

For each resistivity profile, both Wenner-Schlumberger (WS) and Dipole-Dipole (DD) arrays and different electrode spacings were used. However, for the sake of brevity, only the Wenner-Schlumberger results will be described. To calibrate geophysical prospecting, four boreholes were drilled. These were located in three selected urban areas where higher damage was detected from the historical pattern. The drill site locations were also chosen with road accessibility in mind. The locations of the resistivity profiles and boreholes are shown in Fig. 3. This shows that prospecting and drilling were done both on the hill foot and on the hill top. The maximum depth of drilling was $20 \mathrm{~m}$; no water table crosses in any of the holes. However, due to logistical reasons, the geophysical survey was done at the end of winter 


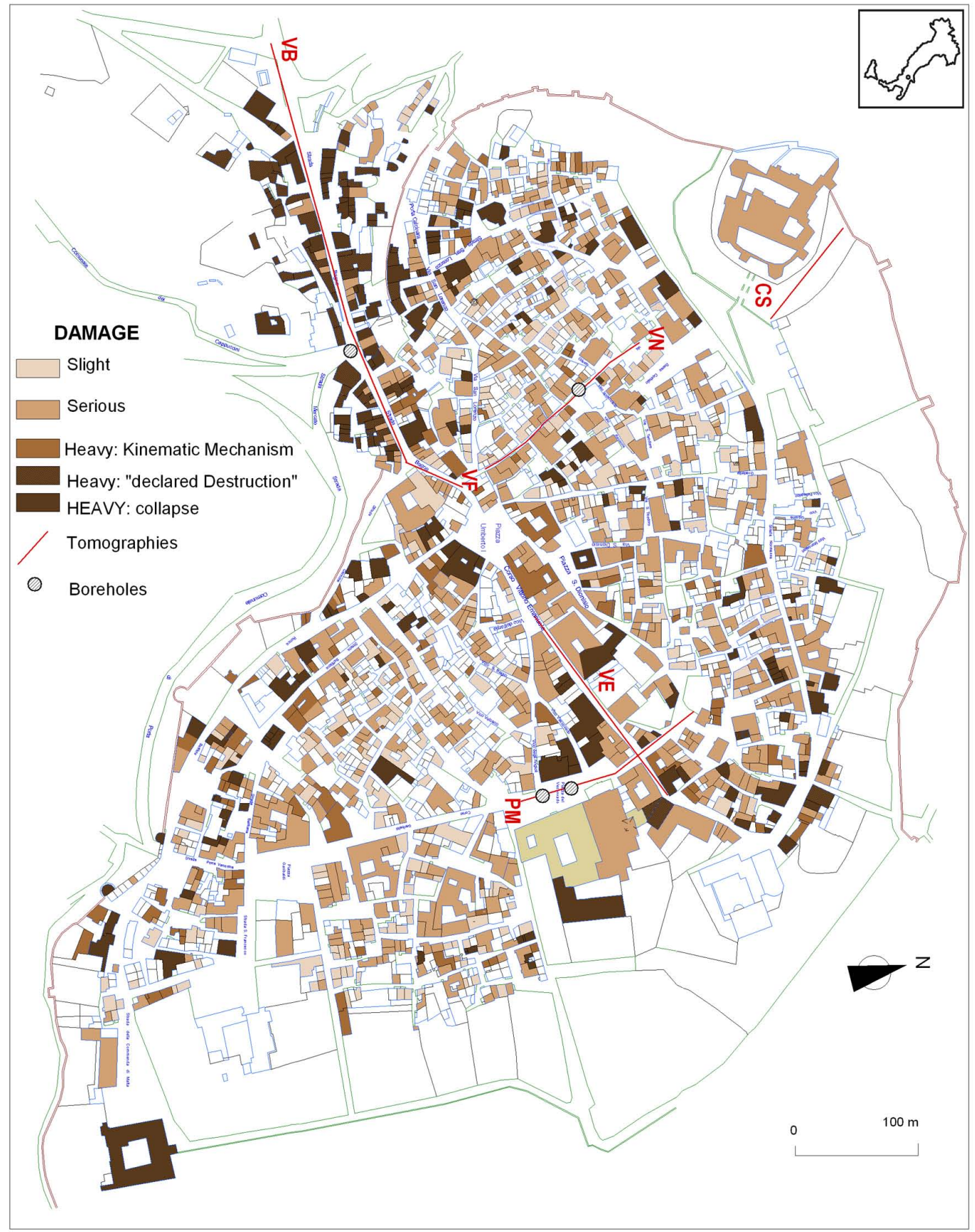

Fig. 3. Damage effects in Melfi downtown. The figure shows both the location of the tomographies and boreholes.

(March), while boreholes were drilled in the summer (August). This preamble is essential to realize geophysical data that will be discussed in the following paragraphs.

The ERT data were elaborated using RES2DINV inversion software (Loke, 2003). The 2-D inversion routine applies a Gauss-Newton least squares method (Loke and Barker, 1996), based on a finite difference model of the subsurface, automatically adjusted in an iterative process. The latest re- sult is obtained by comparing the measured apparent resistivity with the calculated apparent resistivity obtained from the inverted model. To better define the boundaries of the waste landfill, we applied a robust inversion approach. This method attempts to minimise the absolute changes in resistivity values, producing models with sharp interfaces, such as buried boundaries in an urban area. Moreover, a topographic correction with a least-squares straight line trend removal has 


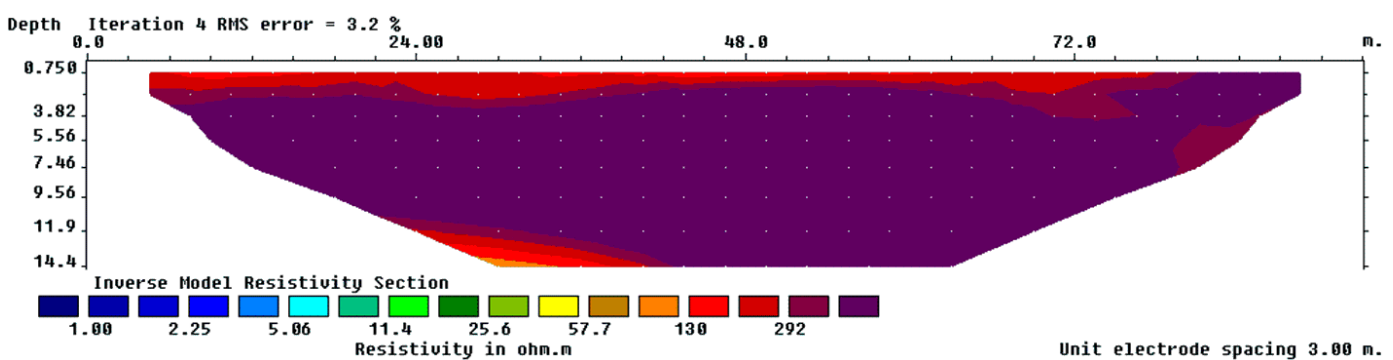

Fig. 4. ERT "Castello" (CS) with topographic corrections. The profile shows a homogenous high electrical resistivity zone (>300 Ohm.m).
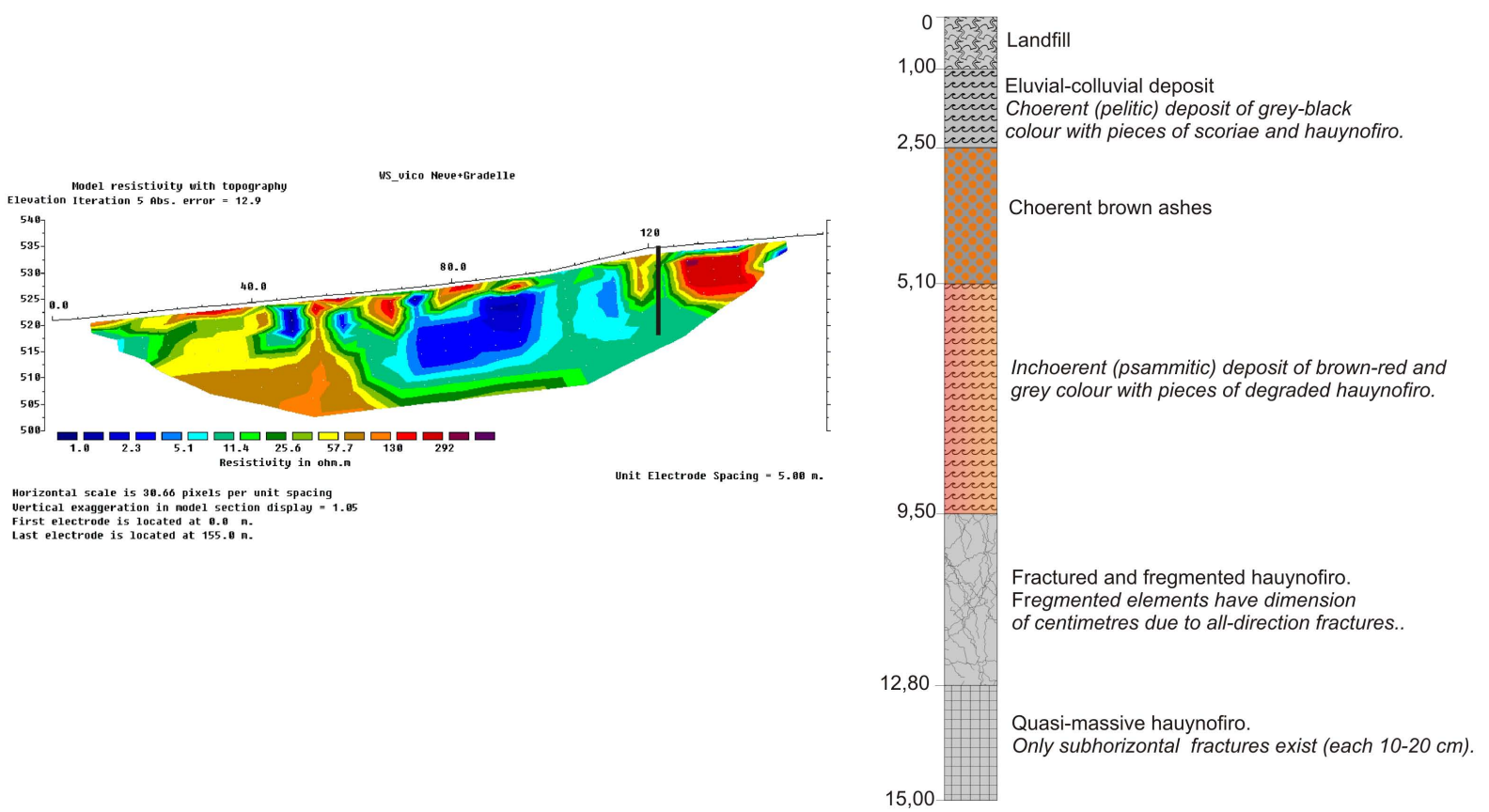

Fig. 5. ERT "Vico Neve" (VN). In depth, a well contact between a relative resistivity zone ( $>60$ Ohm.m) and a relative conductive zone $(<60$ Ohm.m) at $55-60 \mathrm{~m}$ from the origin is highlighted. The Figure also shows the borehole log.

been applied. In order to have an optimal topographic correction, a "distorted finite-element grid with damped distortion" method with a damping factor of 0.75 has been incorporate into inversion model.

The tomography was performed using a WS configuration with a minimum electrode spacing of $5 \mathrm{~m}$ to investigate depths up to about $23 \mathrm{~m}$ with a profile length of $155 \mathrm{~m}$.

For geophysical prospecting on the hill top, the first step was to obtain the resistivity of the Haüynofiro to calibrate the tomography. For this purpose, we carried out an ERT survey in an area where the rock outcrops. The results of the ERT survey "Castello" (CS) with topographic corrections are shown in Fig. 4. A WS configuration with a minimum electrode spacing of $3 \mathrm{~m}$ was used to investigate depths up to around $14 \mathrm{~m}$. The profile was $93 \mathrm{~m}$ long; a homogenous high electrical resistivity zone ( $>300$ Ohm.m) was observed.
The results of the ERT survey "Vico Neve" (VN) are shown in Fig. 5 with topographic corrections.

The ERT image shows a resistivity range from 1 to $400 \mathrm{Ohm} . \mathrm{m}$. On the surface, an electrical heterogeneity is observed, characterized by high and low resistivity nuclei. In depth, a well contact between a relatively resistive zone $(>60 \mathrm{Ohm} . \mathrm{m})$ and a relatively conductive zone $(<60$ Ohm.m) $55-60 \mathrm{~m}$ from the origin is highlighted. Taking into account the borehole log, located about $120 \mathrm{~m}$ from the tomography origin, some interpretations are possible.

The shallow deposits (about $13 \mathrm{~m}$ ) are correlated with covering deposits of the massive Haüynofiro rock, such as eluvial-colluvial sediments, pyroclastic deposits and fractured/altered lava rock. As discussed in the following paragraph, territorial surveys showed a high thickness variability of the covering deposits, from some decimetres to a few metres. 


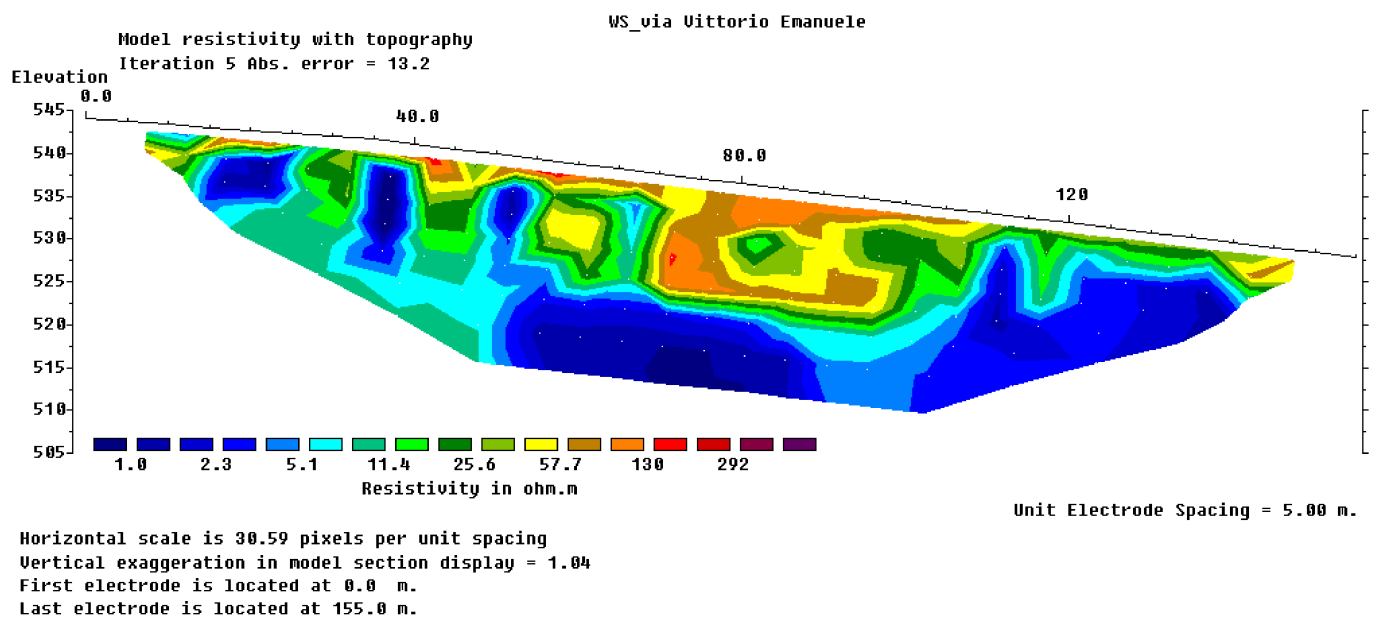

Fig. 6. "Via Vittorio Emanuele" (VE) ERT with topographic corrections. The tomography image highlights a surface heterogeneous electrical layer. Moreover, a relative high electrical resistivity area is located between 70 and $100 \mathrm{~m}$ from the origin.

The results of the "Via Vittorio Emanuele" (VE) ERT survey with topographic corrections are shown in Fig. 6. The tomography image highlights a surface heterogeneous electrical layer with low and high resistivity nuclei and a deep homogenous conductive zone $(<10 \mathrm{Ohm} . \mathrm{m})$. Moreover, a relatively high electrical resistivity area (between 60 and $200 \mathrm{Ohm} . \mathrm{m}$ ) is located between 70 and $100 \mathrm{~m}$ from the origin. The highlighted body has a maximum depth of $10 \mathrm{~m}$.

The "Piazza Marconi" (PM) ERT tomography line (Fig. 7) detects a surface heterogeneous electrical layer of less then $5 \mathrm{~m}$ with low and high resistivity nuclei. Moreover, the deep electrical image highlights a homogenous relatively conductive zone $(<20$ Ohm.m)

Two boreholes drilled in "Piazza Marconi" suggest that shallow deposits found in both "Via Vittorio Emanuele" and "Piazza Marconi" may be correlated to eluvial-colluvial sediments and fractured Haüynofiro. With regards to the deeper portion (at least 10-12 m), geological surveys allowed to infer the presence of lacustrine and alluvial sediments made up of epiclastic deposits, with sands and pelites with both massive and parallel lamination. Lacustrine deposits have a lenticular attitude with thick reducing to the north-west, which is approximately at the centre of the hill top.

Regarding hill foot geophysical prospecting, two tomography surveys were carried out: "Via Nitti" and "Via Bagno."

The results of the "Via Nitti" (VF) ERT survey with topographic corrections are shown in Fig. 8a. The tomography shows a resistivity range from 1 to $400 \mathrm{Ohm} . \mathrm{m}$. The surface electrical image indicates several high and low resistivity nuclei. In depth, a relatively conductive homogenous zone $(<25 \mathrm{Ohm} . \mathrm{m})$ is observed. More conductive nuclei are probably due to hanging water tables that were not detected by drilling for the above-mentioned reasons. The time span elapsed between prospecting and borehole drilling may ex- plain the seeming differences between the two types of investigations.

The "Via Bagno" (VB) tomography image (Fig. 8b) indicates a heterogeneous surface electrical layer and a homogenous deep electrical layer with resistivity between 12 and $40 \mathrm{Ohm} . \mathrm{m}$. Moreover, a relative highly resistive nucleus (between 50 and $100 \mathrm{Ohm} . \mathrm{m}$ ) is located $60 \mathrm{~m}$ from the origin at a depth of $5 \mathrm{~m}$.

The "join" of the ERT "via Nitti and via Bagno" tomography lines is shown in Fig. 8c. This tomography was carried out along the same profile of the "Via Nitti" and "Via Bagno," using some of the same small holes dug for the electrodes. A WS configuration with a minimum electrode spacing of $10 \mathrm{~m}$ was used to investigate depths up to around $45 \mathrm{~m}$. The profile was $310 \mathrm{~m}$ long.

From an electrical resistivity point of view, the heterogeneous surface electrical layer is observed and a relatively low resistivity zone is located at depth. Moreover, between 150 and $160 \mathrm{~m}$ from the origin of the profile, there is a vertical electrical structure (between 25 and $60 \mathrm{Ohm} . \mathrm{m}$ ).

Correlating these data with the borehole log, it emerges that the subsoil is mainly made up of pyroclastic deposits such as ashes. The shallow portion (max. 5-6 m) of the building foundation soil is mainly composed of incoherent grey ashes with sporadic scoriae. At greater depths $(5-20 \mathrm{~m})$, coherent ashes alternate with cemented ones with a level with a high percentage of organic matter between 8 and $8.50 \mathrm{~m}$ were founded. 

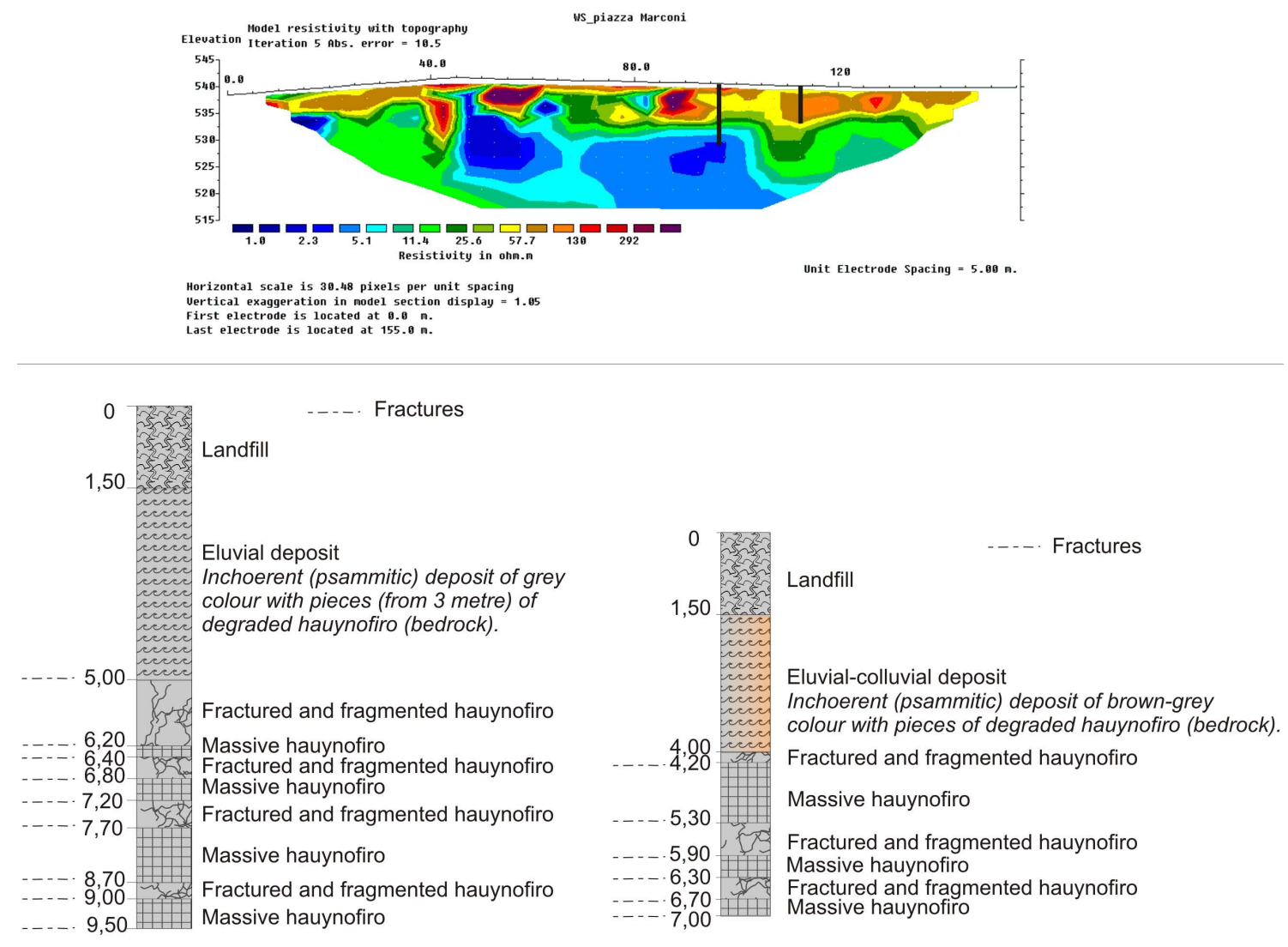

Fig. 7. "Piazza Marconi" (PM) ERT tomography. detects a surface heterogeneous electrical layer of less then $5 \mathrm{~m}$ with low and high resistivity nuclei. Moreover, the deep electrical image highlight a homogenous relative conductive zone ( $<20$ Ohm.m). The figure also shows the borehole logs.

\section{Causes of higher damage: contribution of geophysical-geological surveys and coeval-to- earthquake technical reports}

As mentioned above, geophysical prospecting and geological surveys reveal that the hill on which Melfi is located is made up of Haüynofiro rock covered with highly variable thicknesses of eluvial-colluvial and/or altered/highly fractured Haüynofiro. This is confirmed from an analysis of some grottoes dug beneath buildings. Indeed, grottoes located close to each other are dug both in the lava rock and in the covering deposits. In the grottoes that are too shallow to reach the rock, covering deposits have a thickness of six meters.

On the whole, these data suggest that the sub-soils of some quarters that lie on the hill top have poor geotechnical properties due to presence of several-meter thick covering deposits. Thin deposits with good geotechnical properties (e.g., ashes from 2.50 to $5.10 \mathrm{~m}$ in Fig. 5) can be interposed between deposits with poor geotechnical properties. In both cases, the foundation soils involved from the stress field caused from weight building include deposits prone to cause differential sinking of the building foundation during seismic events.
Seismic amplification due to deposits of poor geotechnical features overlain on massive rocks also occurred on the hill top. This increase is clear from microtremor measurements on lava rock in the eastern portion of the town with a maximum $\mathrm{H} / \mathrm{V}$ spectral ratio reaching 8 in the frequency range $0.1-10 \mathrm{~Hz}$ (Morano, 2002). In this area, the cover is thin but alluvial-lacustrine sediments compose a lens in the Haüynofiro. The seismic velocity inversion may be responsible for the observed amplification. Conversely, the same microtremor analysis shows that pyroclastic deposits outcropping at the hill foot are not able to cause seismic amplification.

Geophysical prospecting and geological surveys indicate highly variable features of the pyroclastic deposits at the hill foot. The presence of shallow and incoherent levels with little thickening and compressible levels with a high percentage of organic matter is common in the eastern part of the Bagni quarter. These lithological features and the stratigraphic setup of the volcanic deposits can cause differential sinking of foundation soils during a seismic event with damage to the buildings. 

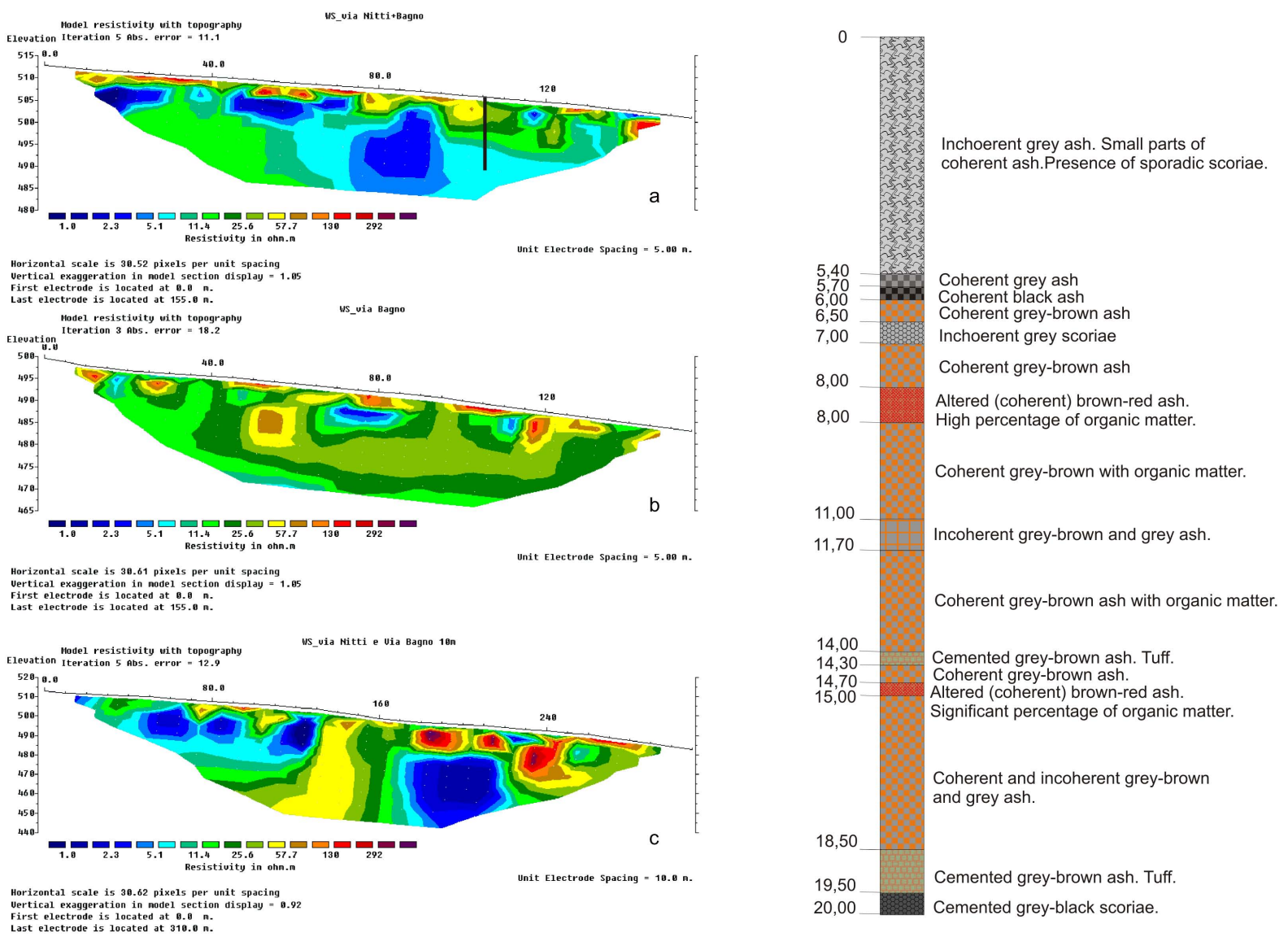

Fig. 8. "via Nitti" (VF) (a), "Via Bagno" (VB) (b) and "via Nitti and via Bagno" (c) tomographies. "via Nitti and via Bagno" tomography was carried out along the same profile of the "Via Nitti" and "Via Bagno" ERT. A WS configuration with minimum electrode spacing of $10 \mathrm{~m}$ was adopted. The figure also shows the borehole carried out in the southern part of the town.

However, data inferred from geophysical prospecting, geological surveys can be combined with an analysis of unpublished technical reports coeval to the 1930 earthquake to infer the causes of higher damage in the southern part of the town.

After the seismic event, the Italian Geological Office (Regio Ufficio Geologico) sent technicians to the damaged area. The role of the experts was both surveying the town damage and to select the areas where to shift the quarter heavily damaged.

The analysis of the technical reports indicates a few factors that caused uneven damage in Melfi. We refer to both geological and "human" features of the town.

Two main causes of differential damage stand out from the technical reports for the quarter at the hill foot where the highest damage occurred during the 1930 earthquake: an earthquake-triggered landslide and instability of grottoes dug underneath the housings. Regarding the first point, a coeval account reports that (translation): “... On this slope lay a quarter (Bagni), the highest damaged neighbourhood. The seismic shocks caused ... a tuff landslide ...”. As regards the second point, the report highlights an increase in dam- age due to instability in grotto vaults in two quarters, BagniCalcinaia and San Martino: “... grottoes were dug in historical times without any consideration of soil stability ...".

To strengthen the statements of accounts, it should be emphasized that the caves show a prevalence of medium-high size with numerous joints in the pyroclastic deposits where they were dug. These features encourage seismic instability of the building-soil system.

In summary, by combining geophysical prospecting, geological surveys and an analysis of technical-historical data, we have inferred four and two probable causes of higher damage at the hill foot and hill top, respectively. Earthquaketriggered landslide, instability of grotto vaults and probable differential sinking of building foundation soils are the causes at the hill foot, while differential sinking of building foundation soil and seismic amplification are the probable causes at the hill top. 


\section{Conclusions}

This paper sheds light on an integrated method adopted to analyse the causes of uneven damage in a town due to a welldocumented historical earthquake. To illustrate the approach, we provide a case study pertaining to a town in southern Italy.

The results emphasize the role played by the multidisciplinary and interdisciplinary approach, based on combining geophysical prospecting, geological surveys and unpublished technical-historical written sources.

In detail, we used geo-electrical prospecting techniques to analyse the geological set-up and to estimate the thickness of shallow deposits. The results of the geophysical surveys were compared with detailed geological information derived from in situ surveys and boreholes. Finally, cross-correlation among these data and technical reports coeval to the seismic event allowed us to gather a complete picture of possible causes of uneven damage.

Acknowledgements. This work was funded by Melfi town Council (Resolution n. 90 of 1 June 2006). The authors would like to thank L. V. Eppelbaum and two anonymous referees for the helpful comments on this paper.

Edited by: L. V. Eppelbaum

Reviewed by: two anonymous referees

\section{References}

Agnesi, V., Camarda, M., Conoscenti, C., Di Maggio, C., Liberto, I.S., Madonia, P., and Rotigliano, E.: A multidisciplinary approach to the evaluation of the mechanism that triggered the Cerda landslide (Sicily, Italy), Geomorphology, 65(1-2), 101116, 2005.

Boschi, E., Guidoboni E., Ferrari G., Mariotti D., Valensise G., and Gasperini P.: Catalogue of Strong Italian Earthquakes from 461 B.C. to 1997, Ann. Geof., 43(4), with CD-ROM, 2000.

Buettner, A., Principe, C., Villa, I. M., and Bocchini, D.: Geocronologia 39Ar - 40Ar del Monte Vulture La geologia del Monte Vulture Ed Principe C (Lavello: Regione Basilicata), 7386, 2006.

Caputo, R., Piscitelli, S., Oliveto, A., Rizzo, E., and Lapenna, V.: High-resolution resistivity tomographies in Active Tectonic studies. Examples from the Tyrnavos Basin, Greece, J. Geod. 36, 1935, 2003.

Cara, F., Cultrera G., Azzara, R. M., De Rubeis, V., Di Giulio, G., Giammarinaro, M.S., Tosi, P., Vallone, P., and Rovelli, A.: Microtremor Measurements in the City of Palermo, Italy: Analysis of the Correlation between Local Geology and Damage, Bull. Seism. Soc. Am., 98(3), 1354-1372, 2008.

Colella, A., Lapenna, V., and Rizzo, E.: High-resolution imaging of the High Agri Valley basin (Southern Italy) with Electrical Resistivity Tomography, Tectonophysics, 386, 29-40, 2004.

Frepoli, A. and Amato, A.: Contemporaneous extension and compression in the Northern Apennines from earthquake fault plane solutions, Geoph. J. Int., 129, 368-388, 1997.

Giammarinaro, M. S, Tertulliani, A., Galli, G., and Leta, M.: Investigation on surface geology and intensity variability in the
Palermo (Italy) urban area after the 6 September 2002, earthquake, Bull. Seism. Soc. Am., 95(6), 2318-2327, 2005.

Giannandrea, P., La Volpe, L., Principe, C., and Schiattarella, M.: Geological Map of Monte Vulture (scale 1:25000), Firenze, 2004.

Giannandrea, P., La Volpe, P., Principe, C., and Schiattarella, M.: Unità stratigrafiche a limiti inconformi e storia evolutiva del vulcano medio-pleistocenico di Monte Vulture (Appennino meridionale, Italia), Boll. Soc. Geol. It., 125, 67-92, 2006.

Gizzi, F. T.: To what degree can historical seismicity records assist in seismic microzonation?, Eng. Geol., 87, 1-12, 2006.

Gizzi, F. T. and Masini, N.: Damage scenario of the earthquake on 23 July 1930 in Melfi: the contribution of technical documentation, Ann. Geophys., 47(5), 1641-1664, 2004.

Guidoboni, E., Mariotti, D., Giammarinaro, M. S., and Rovelli, A.: Identification of amplified damage zones in Palermo, Sicily (Italy), during the earthquakes of the last three centuries, Bull. Seism. Soc. Am., 93(4), 1649-1669, 2003.

Lapenna, V., Lorenzo, P., Perrone, A., Piscitelli, S., Sdao, F., and Rizzo, E.: High-resolution geoelectrical tomographies in the study of the Giarrossa landslide (Potenza, Basilicata), Bull. Eng. Geol. Environ., 62, 259-268, 2003.

Loke, M. H.: Res2dinv-2D Resistivity and IP Inversion. Geotomo Software Malasya, 2003.

Loke, M. H. and Barker, R. D.: Rapid least-square inversion of apparent resistivity pseudosections using a quasi-Newton method, Geoph. Prosp., 44, 131-152, 1996.

Malinverno, A. and Ryan, W. B. F.: Extension in the Tyrrhenian Sea and shortening in the Apennines as a results of a migration driven by sinking of the lithosphere, Tectonics, 5, 227-245, 1986.

Montone, P., Amato, A., Frepoli, A., Mariucci, M. T., and Cesaro, M.: Crustal stress regime in Italy, Ann. Geof., 40(3), 741-757, 1997.

Morano, V.: La microzonazione sismica dell'abitato di Melfi. Degree thesis. Università degli Studi della Basilicata, Potenza, 2002.

Naudet, V., Lazzari, M., Perrone, A., Loperte, A., Piscitelli, S., and Lapenna, V.: Integrated geophysical and geomorphological approach to investigate the snowmelt-triggered landslide of Bosco Piccolo village (Basilicata, southern Italy), Eng. Geol., 98(34),156-167, 2008.

Patacca, E., Sartori, R., and Scandone, P.: Tyrrhenian Basin and Apenninic Arcs: Kinematic relations since late Tortonian times, Mem. Soc. Geol. It., 45, 425-451, 1990.

Patacca, E. and Scandone, P.: Post-Tortonian mountain building in the Apennines. The role of the passive sinking of a relic lithospheric slab The lithosphere in Italy, Advances in Earth Science Research. Proc. It. Nat. Comm. Int. Lith. Progr. Mid-term Conf. (Rome, 5-6 May 1987), Accademia Nazionale dei Lincei, 80, 157-176, 1989.

Pescatore, T., Renda, P., Schiattarella, M., and Tramutoli, M.: Stratigraphic and structural relationship between Meso-Cenozoic Lagonegro basin and coeval carbonate platforms in southern Apennines, Italy, Tectonophysics, 315, 269-286, 1999.

Rizzo, E., Chianese, D., and Lapenna, V.: Integration of magnetometric, gpr and geoelectric measurements applied to the archaeological site of Viggiano (Southern Italy, Agri Valley-Basilicata), Near Surf. Geoph., 3, 13-19, 2005.

Scandone, P., Patacca, E., Meletti, C., Bellatalla,. M., Perilli, N., 
and Santini, U.: Struttura geologica, evoluzione cinematica e schema sismotettonico della penisola italiana Atti del Convegno Annuale del Gruppo Nazionale per la Difesa dai Terremoti (Pisa, 25-27 giugno 1990), 119-135, 1992.
Schiattarella, M., Beneduce, P., Di Leo, P., Giano, S. I., Giannandrea, P. and Principe, C.: Assetto strutturale ed evoluzione morfotettonica quaternaria del volcano del Monte Vulture (Appennino lucano), Boll. Soc. Geol. It., 124, 543-562, 2005. 